\title{
The Monetary Policy Debate Since October 1979: Lessons for Theory and Practice
}

\author{
Marvin Goodfriend
}

\begin{abstract}
Monetary theory and policy have been revolutionized in the two decades since October 1979, when the Federal Reserve under the leadership of Paul Volcker moved to stabilize inflation and bring it down. On the side of practice, the decisive factor was the demonstration that monetary policy could acquire and maintain credibility for low inflation, and improve the stability of both inflation and output relative to potential. On the theory side, the introduction of rational expectations was decisive because it enabled models of monetary policy to incorporate forward-looking elements of aggregate demand and price-setting, long known to be critically important for policy analysis, so as to understand how monetary policy achieved the favorable results found in practice.
\end{abstract}

Federal Reserve Bank of St. Louis Review, March/April 2005, 87(2, Part 2), pp. 243-62.

\section{INTRODUCTION}

$\mathrm{n}$ retrospect, the Federal Reserve tightening of monetary policy begun under the leadership of Paul Volcker in October 1979 stands as a decisive turning point in the postwar monetary history of the United States. With some ups and downs, inflation rose from around 1 percent to over 10 percent in the preceding two decades. The Volcker Fed brought inflation down to around 4 percent by 1984 after a difficult period of sustained disinflationary monetary policy. In the two decades since, inflation has been reduced to a range in 2003 that Chairman Greenspan characterized as "effective price stability," thanks to the consistent inflation-fighting actions of the Greenspan Fed.

The Volcker disinflation and the stabilization of inflation has had an enormous influence on the theory and practice of monetary policy. ${ }^{1}$ This paper reviews how monetary policy has been shaped by that experience. A large part of the story is that central bankers and academic economists learned from each other and both learned

1 See, for instance, Blinder (2004) and Fischer (1994). from evidence accumulated in the conquest of inflation. Monetarist theory and evidence on money supply and demand, and on the relationship between money and inflation, encouraged the Volcker Fed to act against inflation. The successful stabilization and eventual elimination of inflation at reasonable cost in light of subsequent benefits, without wage and price controls, and without supportive fiscal policy actions, vindicated the main monetarist message. However, the Fed's reliance on interest rate policy since then appears to contradict monetarist teaching that money must play a central role in the execution of monetary policy. Modern models of interest rate policy owe more to post-monetarist rational expectations reasoning and notions of credibility and commitment to policy rules born of the rational expectations revolution.

Much macroeconomic theory developed before October 1979 remains at the core of models of monetary policy in use today. The notion of a permanent trade-off between inflation and unemployment has been discredited. However, the forward-looking theory of consumption and

Marvin Goodfriend is senior vice president and policy advisor at the Federal Reserve Bank of Richmond. The paper benefited from conversations with Bennett McCallum, Athanasios Orphanides, and the discussant Larry Ball.

(C) 2005, The Federal Reserve Bank of St. Louis. 


\section{Goodfriend}

investment developed decades ago remains at the core of the modern theory of aggregate demand. And Keynesian dynamic rational expectations sticky-price models of monetary policy pioneered in the late 1970s and early 1980s by Guillermo Calvo, Stanley Fischer, and John Taylor remain at the core of models of aggregate supply today. Keynesian models predict an inverse relationship between the change in inflation and the output gap. That view was confirmed by the severe recession accompanying the Volcker disinflation. Since then, the success in stabilizing inflation has given credence in practice to the rational expectations idea that a central bank committed to making low inflation a priority can anchor inflation expectations and improve the stability of both inflation and output relative to potential.

Section 2 sets the stage for the discussion to follow by reviewing the practice and theory of monetary policy as of October 1979. Section 3 describes the key empirical features of the Volcker disinflation and the lessons that they teach. Section 4 summarizes current consensus views on the theory and practice of monetary policy that emerged from the disinflation experience and related theoretical developments. Topics covered are as follows: the consensus theoretical model of monetary policy, implicit inflation targeting in practice, explicit interest rate policy, and communication policy. In Section 5 we consider current controversies related to each aspect of monetary theory and practice discussed in Section 4.

\section{EXPERIENCE AND THEORY AS OF OCTOBER 1979}

The Volcker Fed was encouraged to embark on a disinflationary course by a practical appreciation of the problems in failing to make low inflation a priority, and by a theoretical understanding that inflation should and could be stabilized and brought down with monetary policy. This section describes the destabilizing go-stop policy cycles that characterized inflationary monetary policy prior to 1979 and summarizes briefly Keynesian and monetarist thinking as it related to the promise and prospects for the stabilization of inflation as of 1979.

\subsection{Inflationary Go-Stop Monetary Policy Prior to 1979}

A combination of factors explains the unprecedented peacetime inflation that tripled the general price level in the two decades prior to the Volcker disinflation. ${ }^{2}$ Most important was the willingness to tolerate each burst of inflation in the expectation that it would soon die down. In retrospect, the public's willingness to accept the upward drift of the price level after World War II was probably the origin of the loss of credibility for low inflation that eventually helped to unhinge inflation expectations in the 1960s and thereafter. There was little understanding at first of the role played by inflation expectations in propagating wage and price inflation and the scope for monetary policy to anchor inflation expectations. Finally, the idea that inflation could permanently reduce unemployment, which gained currency in the 1960s, appeared to provide a benefit to some inflation.

When one adds to the above inclinations and beliefs that the Fed was charged with conducting monetary policy on a discretionary basis, one can understand the go-stop monetary policy that characterized the decades prior to October 1979. During that period the Fed tended to justify periodic actions to contain inflation against an implicit objective for low unemployment. Inflation would rise slowly as monetary policy stimulated employment in the go phase of the policy cycle. By the time the public and Fed became sufficiently concerned about rising inflation for monetary policy to act against it, pricing decisions had already begun to embody higher inflation expectations. At that point, a given degree of restraint on inflation required a more aggressive increase in shortterm interest rates, with greater risk of recession. There was a relatively narrow window of broad public support for the Fed to tighten monetary policy in the stop phase of the policy cycle. The window opened after rising inflation was recog-

\footnotetext{
2 See, for instance, Hetzel (1998) and Orphanides (2002).
} 
nized as the major concern and closed when tighter monetary policy caused the unemployment rate to begin to rise. Often the Fed did not take full advantage of the window of opportunity to raise rates because it wanted more confirmation that higher rates were called for and it was concerned about the recessionary consequences. Once the unemployment rate peaked and began to fall, however, the public's anxiety about it diminished. And the Fed could fight inflation less visibly by lowering interest rates gradually and prolonging the stop phase of the policy cycle. ${ }^{3}$

The tolerance for rising inflation and the sensitivity to recession meant that go-stop cycles became more inflationary over time. The average unemployment rate rose, too, perhaps because increasingly restrictive monetary policy was needed on average to prevent inflation from rising still faster. Aggressive price- and wage-setting behavior tended to neutralize the favorable employment effects of monetary stimulus in the go phase of the policy cycles. As the Fed attempted to offset these unfavorable developments, inflation and expected inflation moved higher. Lenders demanded unprecedented inflation premia in long-term bond rates, and the absence of an anchor for inflation caused inflation expectations and long bond rates to fluctuate widely.

\subsection{The Theory of Monetary Policy as of October 1979}

James Tobin's (1980) comprehensive review of stabilization policy written for the 10th anniversary of the Brookings Papers on Economic Activity contains a good summary of macroeconomic theory as it related to monetary policy, unemployment, and inflation at the time. The five main points of what he calls the consensus macroeconomic framework, vintage 1970, are as follows ${ }^{4}$ :

\footnotetext{
3 Friedman (1964) discusses go-stop monetary policy. Also, see Goodfriend (1997) and Shapiro (1994). Taylor (1979) provides quantitative evidence that can be interpreted as inefficient go-stop policy. See, especially, his Figure 1. Romer and Romer (1989) document that since World War II the Fed tightened monetary policy decisively to contain inflation on six occasions: October 1947, September 1955, December 1968, April 1974, August 1978, and October 1979. The unemployment rate rose sharply each time.

4 The five points are taken from Tobin (1980, pp. 23-25).
}

(1) Prices are marked up labor costs, usually adjusted to normal operating rates and productivity trends... and rates of price and wage increase depend partly on their recent trends, partly on expectations of their future movements, and partly on the tightness of markets for products and labor.

(2) Variations in aggregate demand, whether a consequence of policies or of other events, affect the course of prices and output, and wages and employment, by altering the tightness of labor and product markets, and in no other way.

(3) The tightness of markets can be related to the utilization of productive resources, reported or adjusted unemployment rates, and capacity operating rates. At any given utilization rate, real output grows at a steady pace...reflecting trends in supplies of labor and capital and in productivity. According to Okun's law, in cyclical fluctuations each percentage point of unemployment corresponds to 3 percent of GDP [gross domestic product].

(4) Inflation accelerates at high employment rates because tight markets systematically and repeatedly generate wage and price increases in addition to those already incorporated in expectations and historical patterns. At low utilization rates, inflation decelerates, but probably at an asymmetrically slow pace. At the Phelps-Friedman "natural rate of unemployment," the degrees of resource utilization generate no net wage and price pressures up or down and are consistent with accustomed and expected paths, whether stable prices or any other inflation rate. The consensus view accepted the notion of a nonaccelerating inflation rate of unemployment (NAIRU) as a practical constraint on policy, even though some of its adherents would not identify NAIRU as full, equilibrium, or optimum employment.

(5) On the instruments of demand management themselves, there was less consensus. The monetarist counterrevolution had provided 


\section{Goodfriend}

debate over the efficacy of monetary and fiscal measures, the process of the transmission of monetary policies to total spending, and the proper indicators and targets of monetary policy.

Remarkably, much of this consensus remains at the core of modern mainstream models of monetary policy today, as discussed in Section 4.

Tobin was more pessimistic than other Keynesian economists, such as Arthur Okun (1978), that disinflationary monetary policy alone could bring down inflation at an acceptable unemployment cost. Tobin's views are worth recalling because they capture the more pessimistic Keynesian thinking about the power of monetary policy to control inflation, and they provide some contrast with more optimistic monetarist views discussed below that gained currency in the inflationary decades prior to October 1979. For instance, in the same paper, we learn that Tobin thought that the path of real variables would have been disastrously worse had the path of nominal GDP growth been held to 4 percent per year since 1960. He regarded "the inertia of inflation in the face of nonaccommodative policies [as] the big issue." Tobin's view was that "the price- and wagesetting institutions of the economy have an inflation bias. Consequently, demand management cannot stabilize the price trend without chronic sacrifice of output and employment unless it is assisted, occasionally or permanently, by direct incomes policies of some kind."5 A few pages later Tobin says that he thinks it would be "recklessly imprudent to lock the economy into a monetary disinflation without auxiliary incomes policies."6

Monetarists led by Milton Friedman, Karl Brunner, and Allan Meltzer were optimistic that the Fed could and should use monetary policy alone to bring inflation down. Monetarist theory and its prescriptions for monetary policy were based on the quantity theory of money, evidence from many countries showing that sustained inflation was associated with excessive money growth,

\footnotetext{
5 Tobin (1980, p. 64).

6 Tobin (1980, p. 69).
}

and evidence that inflation could be stopped by slowing the growth of the money supply. ${ }^{7}$

In particular, monetarists demonstrated convincingly that the demand for money was sufficiently stable in the United States to enable the central bank to bring the inflation rate down by reducing the trend rate of growth of the monetary aggregates. And monetarists argued successfully that, although the introduction of money substitutes could adversely impact the stability of money demand in the short run, money demand was sufficiently stable and money supply sufficiently controllable by a central bank over time that financial innovations did not fundamentally alter the central bank's power over inflation. By assembling a convincing body of theory and evidence that controlling money was necessary and sufficient for controlling inflation, and that a central bank could control money, monetarists laid the groundwork for the Volcker Fed to take responsibility for inflation after October 1979 and bring it down.

Monetarists, however, like Keynesians, believed that a disinflation would be costly. Previous experience with go-stop policy made it clear that there was a short-run unemployment cost of fighting inflation. The temporary unemployment cost of a large permanent disinflation would likely exceed the cost of previous temporary attempts to contain inflation in the stop phase of the policy cycle. Both Keynesians and monetarists then understood that the unemployment cost of permanent disinflation could be reduced greatly if the Fed could acquire credibility for low inflation. ${ }^{8}$ In a credible disinflation, money growth and inflation would slow together, with little increase in unemployment. ${ }^{9}$

On the other hand, if the disinflation were not credible, then wage and price inflation would

\footnotetext{
7 See, for example, Friedman (1968, 1989), Meltzer (1963), Poole (1978), Sargent (1986), and the regular reports of the Shadow Open Market Committee led by Karl Brunner and Allan Meltzer.

8 Fellner (1979), Sargent (1986), and Taylor (1982) contain early discussions of the role of credibility in minimizing the cost of disinflation.

9 In fact, Ball (1994) pointed out that a fully credible disinflation could produce a temporary increase in employment for some sticky price specifications.
} 
continue as before, and the public would drive interest rates up and asset prices down as it competed for increasingly scarce real money balances. In that case, unemployment would rise and come down only as the disinflation gained credibility, wage and price inflation slowed, interest rates fell, asset prices rose, and aggregate demand rebounded.

Monetarists tended to be more optimistic than Keynesians about the potential role for credibility because monetarists saw a greater role for expectations in wage and price setting and a smaller role for inertia. And monetarists thought that monetary policy could exert a greater influence over expected inflation than did Keynesians. At any rate, in October 1979 it was not at all clear how quickly the Volcker Fed could acquire credibility for low inflation, how costly a disinflation might be, or even whether it could succeed at all, given the pressure that would be brought to bear on the Fed as a result of the accompanying recession.

\section{LESSONS FROM THE VOLCKER DISINFLATION}

By October 1979 the level and volatility of inflation and inflation expectations resulting from two decades of inflationary go-stop monetary policy greatly complicated the pursuit of stabilization policy. Large real interest rate policy actions were necessary to stabilize the economy. Moreover, it became increasingly difficult to track the public's inflation expectations to tell how nominal federal funds rate policy actions translated into real rate actions. The public found it increasingly difficult to discern the Fed's policy intentions, and the Fed found it increasingly difficult to gauge the state of the economy and how the economy would respond to its policy actions. The opportunity for policy mistakes was enlarged. In short, there was a breakdown in mutual understanding between the public and the Fed.

The Fed rarely sought publicity for its monetary policy actions. However, confidence had deteriorated to such an extent by October 1979 that the Fed broke sharply with tradition and grabbed the headlines with a dramatic high-profile announcement that it had changed operating procedures to place greater emphasis on controlling money. ${ }^{10}$ That dramatic announcement served three main purposes: (i) it associated the Fed with monetarists and thereby bought some credibility against inflation, (ii) it enabled the Fed to blame high interest rates on tighter monetary control, and (iii) it signaled that the Fed would take responsibility for inflation and staked the Volcker Fed's reputation on containing inflation in order to build the Fed's credibility as an inflation fighter. Importantly, the Volcker Fed did not talk much about disinflation in October 1979. Its public statements and Federal Open Market Committee (FOMC) transcripts from the fall of 1979 make clear that its objective was more modest: to stabilize and contain an increase in inflation and inflation expectations. A reading of the FOMC transcripts also makes clear that the Fed came to regard disinflation as a feasible and preferable course of action only gradually as events unfolded in 1980 and 1981. What follows is a brief summary of the key aspects of the Volcker disinflaton and their lessons for monetary policy. In reviewing these events we will see why and how the Volcker Fed produced the sustained disinflation.

\subsection{Loss of Room to Maneuver}

The big surprise for the Volcker Fed in the months after October 1979 was that its room to maneuver between fighting inflation and fighting recession disappeared. ${ }^{11}$ In effect, the Fed lost the leeway to choose between stimulating employment in the go phase of the policy cycle and fighting inflation in the stop phase. The Volcker Fed raised the nominal federal funds rate by about 3 percentage points in the fall of 1979 in its opening fight against inflation. But evidence that the economy was moving into recession caused the Fed to pause in its aggressive tightening. January 1980 later turned out to be a National Bureau of Economic Research business cycle peak, validating

\footnotetext{
${ }^{10}$ See Lindsey, Orphanides, and Rasche (2005).

${ }^{11}$ See, for instance, FOMC (1980; Report on Open Market Operations, February 4-5, pp. 3-4; and Joseph F. Ziesel, Chart Show, February 5).
} 
the Fed's concern about a recession. But with the federal funds rate held steady, the 30-year (long) bond rate jumped by around 2 percentage points between December and February, despite a weakening economy. A number of factors contributed to the unprecedented collapse of bond prices and increase in inflation expectations evident in the sharp rise in the bond rate. Among the most important were the spike in inflation in early 1980, the ongoing increase in oil prices, the incredible rise in the price of gold to around $\$ 850$ per ounce in January, and the Soviet invasion of Afghanistan. That said, the Fed's hesitation to tighten policy at the first sign of recession probably contributed to the inflation scare by creating doubts in the public's mind of the Fed's willingness to incur the unemployment cost to contain inflation.

The unprecedented challenge to its credibility as an inflation fighter made clear that the Fed had lost the flexibility to use interest rate policy to stabilize employment and output. The Fed reacted aggressively to the inflation scare by raising the federal funds rate 3 percentage points to 17 percent in March! The short recession that occurred in the first half of 1980 resulted from the tightening of monetary policy in conjunction with the imposition of credit controls. ${ }^{12}$ When the magnitude of the downturn became clear, however, the Fed cut the federal funds rate by around 8 percentage points between April and July to act against it. Real GDP fell anyway, at around a 10 percent annual rate in the second quarter. But the recession ended quickly with the aggressive easing of monetary policy and the lifting of credit controls in June, and real GDP bounced back with 8 percent annual growth in the fourth quarter of 1980. Unfortunately, inflation remained high throughout 1980.

\subsection{Tactics, Credibility, and Cost}

Observing the resurgence of economic activity, the Fed quickly moved the federal funds rate back up by early 1981 to 19 percent. As measured by personal consumption expenditures (PCE) inflation, which was around 10 percent at the time, real short-term interest rates were then a very high

\footnotetext{
${ }^{12}$ See Schreft (1990).
}

9 percent. A recession began in July 1981 that would take the unemployment rate from around 7 percent to nearly 10 percent at the recession trough in November 1982. PCE inflation fell by around 5 percentage points to the 5 percent range by the first quarter of 1982, and the Fed brought the funds rate down by 5 percentage points as well. Thus, the Fed maintained real short-term interest rates of 9 percent, even as the unemployment rate continued to rise. One reason that policy remained extraordinarily tight even after the break in inflation is that the behavior of long bond rates suggested that the Fed's credibility as an inflation fighter continued to deteriorate. ${ }^{13}$ The long rate actually rose by 3 percentage points from January 1981 to more than 14 percent in October, even as the economy weakened. And the bond rate remained in the 13 to 14 percent range until it began to come down in the summer of 1982. Only then, in the third quarter of 1982, did the Fed begin to reduce real short-term interest rates and pave the way for a recovery. Thereafter, inflation stabilized at around 4 percent and real GDP grew by around 6.5 percent and 4.5 percent in 1983 and 1984, respectively.

A number of factors help to explain why the Fed went ahead with the disinflation in 1981 and why the disinflation succeeded. First, the disastrous developments in 1980 taught the Fed that attempting to stabilize inflation at a high level was costly for the following reasons ${ }^{14}$ : (i) High inflation invited inflation scares that the Fed was compelled to counteract by raising short-term real interest rates, with great risk of recession; (ii) high inflation invited interventions, such as credit controls, that could be equally damaging to the economy; and (iii) containing inflation at a high level would likely require the Fed to maintain a larger average output gap than otherwise to prevent inflation from rising further.

Second, the events of 1980 heightened the public's unhappiness with high inflation. Public

\footnotetext{
${ }^{13}$ A reading of the 1981 transcripts reveals the FOMC's concern with high long-term interest rates and the high inflation expectations that they reflect. For instance, see Chairman Volcker's remarks on page 39 of the August 18, 1981, transcript.

${ }^{14}$ For instance, see Chairman Volcker's remarks in the FOMC transcript from July 7, 1981, p. 36.
} 
support, together with the support of the new Reagan administration, encouraged the Volcker Fed to pursue disinflationary monetary policy in 1981.

Third, the Fed did the hard work of raising the federal funds rate to 17 percent in the spring of 1980. The Fed then took advantage of the window of opportunity that presented itself during the rebound in economic activity in the second half of 1980 to return the federal funds rate to that range. Moving the federal funds rate back up aggressively signaled the Fed's commitment and determination to renew the fight against inflation in 1981. By positioning itself with a 19 percent nominal, and 9 percent real, federal funds rate, the Fed could then let the economy disinflate without having to raise the nominal funds rate further and could lower the nominal federal funds rate as the disinflation took hold.

\subsection{The Inflation Scare Problem and Preemptive Interest Rate Policy}

Severe credibility problems flared up during the Volcker era as "inflation scares" in the bond market-falling bond prices due to sharply rising inflation premia in long-term interest rates. ${ }^{15}$ Inflation scares presented the Fed with a costly dilemma: Ignoring them could encourage more skepticism about the Fed's fight against inflation, but raising real short rates in response risked precipitating a recession or worsening a recession already in progress. There were four prominent inflation scares in the Volcker era. As discussed above, the first scare in early 1980 shocked the Fed into a 3-percentage-point tightening of the federal funds rate in March and was pivotal in persuading the Fed to pursue a more explicitly disinflationary course. The second scare in 1981, with bond rates remaining high through mid-1982, contributed to the Fed's prolonging the 1981-82 recession.

The third inflation scare took the long-term rate from the 10 percent range in mid-1983 to over 13 percent in the summer of 1984. Remarkably, the bond rate was then only about 1 percentage point below its peak in 1981 even though inflation

${ }^{15}$ See Goodfriend (1993), Gurkaynak, Sack, and Swanson (2003), Ireland (1996), and Orphanides and Williams (2005). was about 6 percentage points lower in 1984 and inflation remained in the 4 percent range throughout the inflation scare of 1983-84! In this case, the Fed followed the long rate up with the federal funds rate, taking the funds rate up by around 3 percentage points to the 11 percent range in mid1984 before the bond rate began to come down. The bond rate then fell by 6 percentage points to the 7 percent range by early 1986, about 3 percentage points below where it had been at the start of the inflation scare. The Fed's aggressive containment of the scare apparently made the public confident of another 3-percentage-point reduction in the trend rate of inflation.

The successful containment of the 1983-84 inflation scare was the most remarkable feature of the Volcker disinflation. The Fed had succeeded in reducing inflation temporarily in many preceding go-stop policy cycles. ${ }^{16}$ Preemptive interest rate policy actions in 1983-84 finally put an end to inflationary go-stop policy. This success was particularly important for the future because it showed that well-timed, aggressive interest rate policy actions could defuse an inflation scare and preempt rising inflation without creating a recession.

The Volcker Fed was confronted with a fourth inflation scare in 1987, the last year of Chairman Volcker's leadership of the Fed. The 1987 scare was marked by a 2-percentage-point rise in the bond rate between March and October. This time the Volcker Fed reacted little to the scare, perhaps because GDP growth was weaker than in 1983-84 and there was less risk of an increase in the actual inflation rate. In light of the Volcker Fed's demonstrated determination to act against inflation earlier in the decade, however, the 1987 scare was striking evidence of the fragility of the credibility of the Fed's commitment to low inflation.

\section{CONSENSUS THEORY AND PRACTICE OF MONETARY POLICY}

The period since October 1979 has seen a considerable convergence in the theory and prac-

${ }^{16}$ This point is emphasized by Shapiro (1994). 
tice of monetary policy. On the theory side, New Neoclassical Synthesis models (alternatively called New Keynesian models) of monetary policy embody key components from Keynesian, monetarist, rational expectations, and real business cycle macroeconomics. On the policy side, it is widely agreed that central banks can and should use monetary policy to maintain low inflation over time and that the commitment to price stability enhances the power of monetary policy to stabilize employment over the business cycle. The agreed-upon desirability and feasibility of a priority for price stability was born of the practical experience reviewed above in conjunction with theory developed since October 1979.

In what follows, we review the nature and origin of key elements of the current consensus. First, we review the components of the consensus theory of monetary policy. Second, we review the reasons for the rise of implicit inflation targeting as the strategy of monetary policy in practice. Third, we explain the emergence of explicit interest rate policy as the means of implementing, discussing, and analyzing monetary policy. Fourth, we discuss the transition from the practice of secrecy to transparency in communicating monetary policy actions, concerns, and intentions to the public.

\subsection{The Consensus Model}

The modern New Neoclassical Synthesis (or New Keynesian) consensus macroeconomic model of monetary policy is a dynamic general equilibrium model with a real business cycle core and costly nominal price adjustment. The consensus model and its implications for monetary policy have been exposited from somewhat different perspectives in Goodfriend and King (1997), Clarida, Galí, and Gertler (1999), Woodford (2003), and Goodfriend (2004). ${ }^{17}$ A convergence in thinking is clear from a reading of these diverse expositions. The heart of the baseline model is compactly represented by the following two equations.

There is a "forward-looking IS function" in which current aggregate demand relative to poten-

${ }^{17}$ See also the papers in Mankiw and Romer (1991). tial output depends positively on expected future income and negatively on the short-term real interest rate. It resembles the original Keynesian IS function except for its reliance on expected future income. The dependence of current aggregate demand on expected future income dates back to the theory of consumption developed by Fisher (1930) and Friedman (1957).

There is an "aggregate supply function," also called a price-setting function, that relates current inflation inversely to the current markup (or output gap) and expected future inflation. This aggregate supply function can be derived directly from Calvo's (1983) model of staggered price setting and is closely related to the pioneering work of Stanley Fischer and John Taylor (see Taylor, 1999b).

The modeling of expected future income in the IS function and expected future inflation in the aggregate supply function reflects the introduction of rational expectations into macroeconomics by Robert Lucas in the 1970s. ${ }^{18}$ Rational expectations theory and solution methods provided a convincing and manageable way to model expectations. Moreover, rational expectations theory taught that it is critically important in analyzing monetary policy to let expectations rationally reflect changes in the way that monetary policy is imagined to be conducted.

By solving the IS function forward, it is possible to express current aggregate demand relative to potential in terms of the expected path of future short-term real interest rates and future potential output. To the extent that price-level stickiness enables monetary policy to exert leverage over the path of real interest rates, both current and expected interest rate policy actions determine current aggregate demand.

By solving the inflation-generating function forward, one can see that the current inflation rate depends inversely on the path of expected future markups. The model implies that inflation will remain low and stable if monetary policy manages aggregate demand to stabilize the output gap to keep the average markup at the profitmaximizing markup. In other words, monetary

\footnotetext{
${ }^{18}$ See Lucas $(1976,1981)$.
} 
policy maintains price stability by anchoring expected future markups at the profit-maximizing markup so firms do not wish to change prices. Monetary policy that stabilizes the markup at its profit-maximizing value makes the macroeconomy behave like the underlying core real business cycle model with flexible prices. From this perspective, "flexible price real business cycle models of aggregate fluctuations are of practical interest, not as descriptions of what aggregate fluctuations should be like regardless of the monetary policy regime, but as descriptions of what they would be like under an optimal monetary policy regime."19

Looking back at Tobin's summary of consensus thinking about monetary policy in 1980, much remains from that time. There is the idea that prices are marked up over costs; that price trends depend on expectations and on tightness of labor and product markets; that variations in aggregate demand alter inflation by influencing the tightness of markets; that there is a natural rate of unemployment (where output equals potential) at which wage and price setters perpetuate the going rate of inflation (presumably at the profitmaximizing markup); that inflation accelerates when output is expected to exceed potential (the markup is expected to be compressed); and that inflation decelerates when output is expected to fall short of potential (the markup is expected to be elevated). The main advances since then are due to (i) the proven power of monetary policy to reduce and stabilize inflation and inflation expectations at a low rate and (ii) the progress in modeling expectations rationally to understand how monetary policy consistently committed to stabilizing inflation can achieve favorable results.

The model of monetary policy is closed with a description of how policy is imagined to be conducted. Rational expectations teaches that it is not possible to tell how a monetary policy action influences behavior unless it is modeled as part of systematic policy. Hence, the model cannot be employed to analyze policy actions without specifying how policy is conducted. There are two ways to do this. One can assume that the central bank

${ }^{19}$ Woodford (2003, p. 410). Goodfriend and King (1997) and Goodfriend (2004) emphasize this point. employs a rule for its policy instrument, such as a Taylor interest rate rule or a McCallum monetary base rule. Or one can assume that the central bank chooses its instrument each period to maximize a welfare function, which could be derived to reflect household utility in the model. Each way of closing the model has advantages and disadvantages. An ad hoc policy rule can be chosen to approximate a central bank's reaction function in practice. The problem is that an ad hoc rule is unlikely to be optimal in the model in question. On the other hand, optimal policy in the model may not give rise to a policy rule that a central bank would follow in practice, and it may not be optimal at all if the model is incorrect. ${ }^{20}$ Kydland and Prescott (1977) first pointed out that optimal monetary policy is likely to be time inconsistent and that monetary policy may be suboptimal if a central bank cannot commit to a policy rule. ${ }^{21}$

\subsection{Implicit Inflation Targeting}

With respect to the practice of monetary policy, the most important development since October 1979 has been the rise of implicit inflation targeting as the core of the Fed's strategy of monetary policy. ${ }^{22}$ This is remarkable in retrospect because no one would have predicted it in October 1979. For instance, although monetarists insisted that price stability ought to be the primary goal of monetary policy, their reading of monetary history suggested that the inflation rate itself could not serve as a practical guide for monetary policy and an operational criterion for performance because of the long and variable lags of nearly two years in the effect of monetary policy on inflation. ${ }^{23}$ Hence, monetarists recommended monetary targeting as the means by which a central bank should control the inflation rate.

\footnotetext{
${ }^{20}$ See McCallum (1999) and Svensson (1999).

${ }^{21}$ See, also, Barro and Gordon (1983).

22 The Fed does not have a formal inflation target. But Goodfriend (2003b) argues that monetary policy conducted by the Greenspan Fed may be characterized as a form of implicit inflation targeting. See Bernanke and Mishkin (1997) for a formal definition of inflation targeting.

${ }^{23}$ See Friedman (1960, pp. 87-88).
} 


\section{Goodfriend}

The rise of implicit inflation targeting is the result of a number of factors. ${ }^{24}$ Most important, the Fed has shown that a consistent commitment to price stability can stabilize inflation within a relatively narrow range at a low rate over the business cycle. Second, the unemployment cost (associated with go-stop policy and inflation scares) of failing to make low and stable inflation a priority is now well understood. Third, anchoring inflation expectations is understood to produce three critical benefits: (i) It helps the Fed to know how its nominal federal funds rate target changes translate into real interest rate movements, which helps the Fed gauge the likely impact of its policy actions on the economy; (ii) it enables the Fed to buy time to recognize and counteract threats to price stability before they develop into inflation or deflation scares; and (iii) it enhances the flexibility of interest rate policy to react aggressively (without an inflation scare in bond markets) to shocks that threaten to destabilize financial markets and/or create unemployment. Fourth, macroeconomic performance since the Volcker disinflation has produced two of the longest expansions in U.S. economic history, with two of the shortest contractions in 1990-91 and 2001.

\subsection{Explicit Interest Rate Policy}

A second practical development of considerable importance since October 1979 has been the Fed's decision since February 1994 to announce publicly its federal funds rate target immediately after each FOMC meeting. This development marked the return to an explicit interest rate policy, last fully acknowledged in the early 1920s. When the Fed embarked on its first campaign to tighten monetary policy in the aftermath of World War I, it did so with widely publicized increases in its discount rate, which the public then understood to anchor money market rates in much the same way the Bank of England's "bank rate" had anchored rates since the 19th century. ${ }^{25}$ High interest rates were suspected to have caused the

\footnotetext{
${ }^{24}$ Feldstein (1997) and Schmitt-Grohé and Uribe (2002), for instance, provide quantitative support for making low inflation a priority.

${ }^{25}$ See Hawtrey (1938).
}

deflation and recession of 1920-21. According to Meltzer's (2003) account, it is no exaggeration to say that the Fed was traumatized by its first use of open interest rate policy. ${ }^{26}$ Shortly after that experience, the Fed moved to adopt operating procedures to pursue interest rate policy less visibly. It did so by targeting borrowed reserves.

Borrowed-reserve targeting enabled the Fed to talk about monetary policy in terms of the "degree of pressure on reserves," rather than in terms of interest rates, and to create the illusion that money market rates were determined largely if not completely by market forces. There were three reasons for this. ${ }^{27}$ Money market rates floated relative to the discount rate, with a spread that fluctuated with credit risk and the volume of bank reserves that the Fed forced the banking system to borrow from Reserve Banks. Money market rates could be manipulated quietly, without changing the high-profile discount rate, by forcing the banking system to borrow more or less of its reserves at the discount window. The Fed could create the impression that visible (discount rate) interest rate policy followed market rates. For instance, if the Fed wanted to raise rates it could first force banks into the window by selling securities. That would raise market rates without raising the discount rate. Later, the Fed could raise and realign the discount rate while buying securities to bring the volume of forced borrowings back down. Of course, the Fed retained the option of leading with discount rate changes when it wanted to grab the headlines.

Thus, borrowed-reserve targeting was noisy interest rate policy in which the Fed continued to manage short-term interest rates closely but in a relatively invisible way. It afforded the Fed a means of implementing interest rate policy actions quietly or loudly, depending on what was called for. ${ }^{28}$ With some notable exceptions, such as the 1974-79 period, until 1994 the Fed often managed

\footnotetext{
${ }^{26}$ See Meltzer (2003, pp. 13, 112-16, and 127).

27 See Goodfriend (2003a).

${ }^{28}$ Goodfriend (1991, p. 21) quotes Governor Strong from 1927 and Chairman Greenspan from 1989, explaining why it is useful for the Fed to have the option to take policy actions quietly or loudly.
} 
short-term interest rates by targeting borrowed reserves. ${ }^{29}$

A number of factors account for the Fed's decision to return to explicit interest rate policy in 1994. The period of high interest rates in the 1970s and 1980s, especially during the Volcker disinflation, gave the Fed a high profile, which it never lost. Greater public scrutiny of monetary policy created pressure for increased transparency of interest rate policy actions. Second, increased instability in the demand for M1 and M2 in the 1980s and early 1990s undermined the case for operating procedures that involved bank reserves and monetary targeting. Third, academic papers (e.g., Goodfriend, 1991, 1993, and Taylor, 1993) began to talk about monetary policy explicitly in terms of interest rates. Fourth, academics learned how to analyze monetary policy in models without money (e.g., Kerr and King, 1996, McCallum, 2001, and Woodford, 2003) and economists at the Board developed models of monetary policy without money (e.g., Brayton et al., 1997). Fifth, with inflation low and stable, the federal funds rate could be expected to move in a relatively low and narrow range. In short, the consensus to implement, discuss, and analyze monetary policy as explicit interest rate policy became overwhelming.

\subsection{Communicating Policy Concerns and Intentions}

A third practical development of importance since October 1979 has been the remarkable increase in transparency in communicating the concerns and intentions of monetary policy in addition to announcing the federal funds rate target. One can understand this transition as a change in the means by which a central bank achieves its primary monetary policy mission: to contribute to macroeconomic stability in a way that leaves maximum freedom of action to private markets. The idea is that monetary policy should be conducted as unobtrusively as possible to mini-

\footnotetext{
${ }^{29}$ Cook and Hahn (1989) point out that the Fed chose to control the federal funds rate so firmly from September 1974 until September 1979 that the public was able to perceive most changes in the target on the day they occurred. The extent to which the Fed employed borrowed reserve targeting from 1979 to 1994 is controversial. See Cook (1989) and Poole (1982) on the 1979-82 period, and Thornton (2004) on the period after 1982-84.
}

mize interference in markets. Hence, central banks developed a reputation for secrecy. ${ }^{30}$ Recent theory and practice reviewed above, however, teaches that a central bank enhances the performance of markets by creating an environment of dependable low inflation. Since transparency creates understanding of the tactics and strategy of monetary policy, transparency rather than secrecy is more apt to strengthen credibility for low inflation. Broadly speaking, that is what accounts for the striking increase in communication with the public that has characterized monetary policy in recent years. ${ }^{31}$

The return to fully explicit interest rate policy in 1994 initiated greater use of communications in support of monetary policy actions. The enhanced visibility of interest rate policy actions increased the public's appetite for transparency and encouraged even more Fed communication with markets. The train of events worked like this: Announcing the federal funds rate targets enabled the federal funds rate futures market to mature. That, in turn, made the path of expected future interest rate policy actions more visible to the public. Market participants and the public began to debate Fed concerns and intentions for future interest rates more openly. By measuring the distance between market expectations and its internal intentions for the future funds rate, the Fed could judge the effectiveness of its communications about monetary policy and how they might be adjusted to achieve a desired effect. The "conversation" between markets and the Fed became particularly important in 2003, when the federal funds rate was 1 percent and the Fed wished to lower the yield curve to fight the deflation risk by steering expected future interest rates lower with language that signaled its intention to be patient in raising interest rates.

Interestingly enough, these developments appear to have re-created the option for the Fed to make interest rate policy actions quietly or loudly. To move interest rates quietly, the Fed moves federal funds rate futures in the desired direction by gradually signaling its intentions

\footnotetext{
${ }^{30}$ Goodfriend (1986).

${ }^{31}$ See Blinder (2004) and Ferguson (2002).
} 


\section{Goodfriend}

through its communications. Later, the Fed simply confirms expectations that it created previously by adjusting its federal funds rate target as expected. On the other hand, if circumstances are such that the Fed wishes to get more attention for its actions, it can surprise markets with federal funds rate policy actions not prepared for in advance. In this way, the Fed can appear either to follow or to lead the market, as it could do with the borrowed-reserve targeting procedures used earlier in its history.

\section{CURRENT CONTROVERSIES}

There are many controversies within the broad consensus described above-on the theory of monetary policy, inflation targeting, interest rate policy, and communications-that matter for the conduct of monetary policy. Some of these are discussed below.

\subsection{Specification and Interpretation of the Monetary Policy Model}

The most important controversies in the theory of monetary policy involve the aggregate supply function (price-setting function), because it determines the nature of the short-run trade-off between inflation and unemployment. ${ }^{32}$ Clearly, shocks to aggregate demand present no conflict between stabilizing inflation around its objective and stabilizing output around potential. What about shocks to aggregate supply? To appreciate the issues, consider first the baseline price-setting function discussed above derived from Calvo (1983), in which current inflation depends positively on expected future inflation and inversely on the current output gap or the current markup. Goodfriend and King (1997, 2001), King and Wolman (1999), and Goodfriend (2002) emphasize that in this baseline case, fully credible price stability keeps output at its potential and employment at its natural rate. In other words, there is no short-run trade-off between inflation and unem-

\footnotetext{
32 The aggregate supply function derived from Calvo (1983) has a small long-run trade-off between unemployment and inflation that is ignored in practical applications.
}

ployment, even for shocks to aggregate supply. ${ }^{33}$ From this perspective, even those who care mainly about output and employment can support strict price stability.

Yet, many would say that the baseline case is not realistic and, indeed, taking other potential features of the macroeconomy into account can overturn the strong implication that price stability is always welfare-maximizing monetary policy. For instance, John Taylor has emphasized a trade-off in the long-run variance of inflation and output relative to potential in models of monetary policy that results from a short-run trade-off in the levels of inflation and unemployment. See, for instance, the papers in Taylor (1999a). Any of the following modifications of the Calvo pricesetting function produce a short-run trade-off in inflation and unemployment, adding (i) a "cost" shock that feeds directly into inflation irrespective of expectations or the current markup, (ii) lagged inflation that reflects structural inflation inertia in the price-setting process, and (iii) nominal wage stickiness to the baseline model, which otherwise presumes that wages are perfectly flexible.

With any of these modifications, it is no longer always possible to stabilize both inflation and output at potential. Monetary policy must create a shortfall of aggregate demand relative to potential output to offset the effect of a cost shock or inertial inflation on current inflation. Nominal wage stickiness creates a trade-off with respect to productivity shocks even without modifications (i) and (ii). To see this, first consider a temporary negative shock to productivity in the baseline model. In that case, markup and inflation stabilization both call for a contraction in aggregate demand to conform to the contraction in potential output. And nominal and real wages both fall with productivity, offsetting the effect of the negative shock to productivity on marginal cost and the markup. Thus, when wages are flexible, monetary policy can simultaneously stabilize the output

\footnotetext{
${ }^{33}$ Fully credible price stability means that current inflation and expected future inflation are identical (and consistent with a lowinflation target). In this case, the Calvo price-setting function implies that actual output equals potential output or, equivalently in the baseline model, that the actual markup equals the profitmaximizing markup.
} 
gap and inflation. Things don't work out as neatly if nominal wages are sticky. ${ }^{34}$ Then, monetary policy must steer aggregate demand below potential (to raise the marginal physical product of labor) to offset the effect of negative productivity growth on marginal cost in order to stabilize the markup and the inflation rate.

Although these modifications seem realistic, there are reasons to question their importance in practice. First, because marginal cost is already taken into account in the underlying theory, strictly speaking there is no role for a "cost" shock in the price-setting function. The statistical residual found in practice might just reflect measurement error or noise in the modeling of expectations. If one argues that some costs flow directly to prices in a perfectly competitive sector, then theory suggests that the central bank should consider stabilizing only a "core" index of monopolistically competitive sticky prices. Second, theory that justifies structural inertia in the inflation-generating process is controversial. ${ }^{35}$ Lags of inflation in an estimated inflation-generating function could reflect persistence introduced into the inflation rate by central bank behavior, especially in the presence of measurement or other specification errors. There is evidence that apparent inflation persistence is reduced when inflation is low and stable. ${ }^{36}$ Third, an inflation target of 1 to 2 percent coupled with productivity growth of around 2 percent produces nominal wage growth in the 3 to 4 percent range. Such high average nominal wage growth should keep the economy away from situations in which significant downward nominal wage stickiness, as opposed to slower nominal wage growth, is required to keep price inflation stable and output at potential.

\subsection{Should the Fed Adopt an Inflation Target?}

Given the Fed's established commitment to low inflation, and the widely agreed-upon benefits

\footnotetext{
${ }^{34}$ See Erceg, Henderson, and Levin (2000).

${ }^{35}$ See Fuhrer and Moore (1995).

${ }^{36}$ See Cecchetti (1995) and Cogley and Sargent (2001).
}

derived from putting a priority on price stability, the question is this: Should the Fed adopt an explicit, numerical target range for inflation and strive to keep inflation in or near that range? This debate is well illustrated by an exchange between Goodfriend (2003b) and Kohn (2005). Goodfriend argues that the Greenspan Fed has been targeting inflation implicitly in the following senses. First, Chairman Greenspan testified in 1989 in favor of a qualitative low-inflation objective for the Fed, defined as a situation in which "the expected rate of change of the general level of prices ceases to be a factor in individual and business decisionmaking." 37 Thus, it is reasonable to think that the Greenspan Fed sought to make that definition of price stability a reality over time. Second, the Greenspan Fed targeted inflation flexibly. It achieved price stability gradually by leaning against rising inflation in the late 1980s, bringing it down gradually in the early 1990s, holding the line on inflation in 1994, and keeping a measure of inflation favored by the Fed, core PCE inflation, in the 1 to 2 percent range thereafter. Third, it is difficult to imagine that, henceforth, the Greenspan Fed deliberately would target core PCE inflation above 2 percent or below 1 percent. Fourth, the Greenspan Fed has implicitly practiced inflation targeting as constrained countercyclical stabilization policy: The Greenspan Fed exploited its credibility for low inflation to lower short-term interest rates aggressively to fight the recession in 2001 and to keep short-term interest rates at historic lows since then to stimulate employment and guard against deflation. Thus, Goodfriend argues that to help perpetuate its current practice of flexible inflation targeting as constrained stabilization policy, the Fed should acknowledge an explicit 1 to 2 percent long-run target range for core PCE inflation.

Contrary to Goodfriend, Kohn (2005) argues that the Fed would not have been able to adapt as flexibly to the changing conditions described above if an explicit inflation target had already been in place. So Kohn would not characterize policy pursued by the Greenspan Fed as implicit inflation targeting. Moreover, Kohn argues that

${ }^{37}$ Greenspan (1990, p. 6). 
even without explicit inflation targeting the economy has enjoyed most of the benefits of low and stable inflation and inflation expectations. He sees little need to adopt a formal inflation target to help perpetuate the focus on price stability in the future. In effect, Kohn thinks that a formal inflation target would exert a needless constraint on countercyclical stabilization policy, in part because he worries that it might be imposed with more unproductive conditions than Goodfriend thinks would be the case.

In return, Goodfriend emphasizes three points. In the long run there are no circumstances in which sustained inflation should or need be much higher or lower than today. Monetary policy best encourages employment and economic growth in the long run by stabilizing inflation and inflation expectations. A central bank has an obligation to inform Congress formally of these lessons learned from theory and experience of monetary policy since October 1979 and to ask to be held accountable for keeping inflation in or near a 1 to 2 percent target range over time in order to improve congressional oversight of monetary policy.

\subsection{Interest Rate Policy with No Role for Money}

It is ironic that monetarists deserve much of the credit for laying the groundwork for the Fed's defeat of inflation, yet the Fed currently ignores money in both the implementation and analysis of monetary policy. ${ }^{38}$ Moreover, monetarists have long emphasized the dangers inherent in implementing monetary policy using the federal funds rate instead of using bank reserves or the monetary base as the policy instrument. ${ }^{39}$ Yet, the Fed has pursued an explicit interest rate policy since 1994. It is worth recalling, then, the nature of the monetarist concerns and to consider more generally the robustness of interest rate policy without any role for money.

Poole (1978) presents the classic monetarist criticism of monetary policy: The Fed has tended to smooth short-term interest rates excessively

\footnotetext{
${ }^{38}$ See Brayton et al. (1997).

${ }^{39}$ McCallum (2000b) presents evidence that monetary base rules performed better over 1970-98 than Taylor-style interest rate rules.
}

over the business cycle in the following sense. ${ }^{40}$ The Fed has been reluctant to raise short-term interest rates promptly and aggressively enough when the economy strengthens after a recession trough; and the Fed has not lowered rates promptly and aggressively enough when the economy weakens at the start of a recession. Hence, interest rate policy has imparted an excessively procyclical bias to money growth that has exacerbated the business cycle. Poole points out that, in the past, the smoothing of short-term interest rates has actually caused both short- and long-term rates to become more volatile over time. Although Poole doesn't mention it, interest rate smoothing probably played a large part in creating the increasingly inflationary and excessively volatile go-stop cycles before October 1979.

The Fed has learned to adjust interest rates more preemptively since October 1979. It moved interest rates aggressively during the Volcker disinflation, and inflationary go-stop policy cycles are no more. A closer look, however, indicates that some residual problems associated with interest rate smoothing in Poole's sense may remain. For instance, the Fed did not respond with higher short-term interest rates during the 1987 inflation scare-and may have held rates too low for too long after the October 1987 stock market crash, given the increase in inflation that followed. On the other hand, the Fed did move aggressively and preemptively to head off rising inflation in 1994, without creating a recession. Later in the decade, though, the Fed may have exacerbated cyclical instability by holding the federal funds rate target too low for too long. ${ }^{41}$

Only time will tell whether the monetarist argument that interest rate policy is inherently destabilizing will reassert itself. Before leaving this point, however, it must be mentioned that Woodford (2003) has shown that "inertial" interest rate policy may be advantageous. Specifically, if interest rate smoothing is measured by the coefficient on $R(t-1)$ in a rule for $R(t)$, the federal funds rate, then Woodford argues that coefficients above 1 (superinertial interest rate rules) may be optimal.

\footnotetext{
${ }^{40}$ Poole (1978, p. 105-10)

${ }^{41}$ See Goodfriend (2002).
} 
Of course, this requires that the rule also respond vigorously to inflation or expected future inflation and possibly to the output gap.

Whatever one thinks about interest rate policy, there are good reasons why money ought to be integrated into the Fed's operating procedures to some extent. First, the Fed should have a contingency plan to implement "quantitative" policy by expanding its balance sheet in case the zero bound becomes a constraint on interest rate policy. Second, the Fed should have a contingency plan for returning to monetary targeting in the event that high and volatile inflation and inflation expectations cause trouble again. Third, the Fed needs to understand better how interest rate policy should be modified to counteract shocks to the production and use of broad money in the presence of extreme asset price movements or crises of confidence in credit markets. ${ }^{42}$

A final, crucial concern about interest rate policy is this: Explicit interest rate policy as conducted by the Fed today relies heavily for its effectiveness on the credibility of the Fed's commitment to price stability. ${ }^{43}$ There has been no explicit nominal anchor for U.S. monetary policy at least since the United States left the gold standard when the Bretton Woods fixed exchange rate system collapsed in $1973 .{ }^{44}$ Six years of monetary chaos after that persuaded the Volcker Fed in October 1979 to work toward establishing an implicit nominal anchor by restoring and maintaining credibility for low inflation. Monetary economists have taught, and central bankers have commonly believed, that monetary policy ought to have an explicit nominal anchor such as a link to gold, a fixed foreign exchange rate, an announced path for a monetary aggregate, or an inflation target. ${ }^{45}$ Yet Congress has not designated one and the Fed has not adopted an explicit nominal anchor to replace the link to gold. Practical and theoretical developments since October 1979 suggest that monetary policy may not need an

\footnotetext{
${ }^{42}$ See Goodfriend (forthcoming).

${ }^{43}$ See Blinder (2000).

${ }^{44}$ The gold standard ceased to provide an effective nominal anchor for monetary policy long before that. See Goodfriend (1988).

${ }^{45}$ See McCallum (2000a).
}

explicit nominal anchor after all, at least in some circumstances. It is debatable, however, whether Fed credibility for low inflation alone will prove to be a robust substitute for an explicit nominal anchor in the face of the monetary policy challenges to come, especially since the Fed's commitment to low inflation needs the support of conforming fiscal policy to be fully credible.

\subsection{Clarifying Short-Run Communications}

Because the Fed does not publicly and explicitly specify a target range for inflation, it must signal its short-run concerns and intentions about inflation and deflation entirely in postFOMC meeting statements and minutes and in the Chairman's speeches and reports to Congress. Problems that the Fed experienced in 2003 in signaling its concern about deflation raise questions as to whether statements and speeches substitute adequately for an explicit inflation target. For instance, the statement following the May 2003 FOMC meeting, that further disinflation was unwelcome, came as a surprise, and media commentary amplified the nervousness about deflation well beyond what was justified. Expected future funds rates fell sharply and pulled longer-term interest rates down sharply as well. The Fed reduced the federal funds rate less than the widely expected 50 basis points at the June meeting, and longer-term interest rates promptly reversed field.

Broaddus and Goodfriend (2004) point out that if an inflation target range had been in place in 2003, the public could have inferred the Fed's growing concern about disinflation gradually as the inflation rate drifted down earlier in the year. Expected future interest rates likely would have come down smoothly with less chance of overshooting the Fed's intended policy stance. The authors went on to assert that this experience illustrates a more general point. Rational expectations reasoning teaches that the public has difficulty gauging the intent of a Fed policy action taken out of context and, therefore, the Fed will find it particularly difficult to predict the effect of an ad hoc unsystematic policy action. Since the announcement that any more disinflation would be unwelcome was ad hoc by definition, it is not 
surprising that it caused confusion. In this case, the reaction was excessive, but in another situation there might have been an insufficient reaction. The point is that the scope for misunderstanding in discretionary communications is great. ${ }^{46} \mathrm{On}$ this basis, a case can be made that an inflation target would be a valuable addition to the Fed's short-run communications procedures. From this perspective, Broaddus and Goodfriend argue, the Fed has authority from Congress to set an inflation target as part of its operational independence.

In the second half of 2003, the Fed had difficulty convincing financial markets of its inclination to maintain a low federal funds rate for a "considerable period." One possible reason, also argued by Broaddus and Goodfriend, is that policy statements emphasized strong real economic growth during the period but paid insufficient attention to the sizable gap in employment and to the cumulative deflation in unit labor costs that had almost certainly widened the gap between actual and profit-maximizing markups. The apparent size of these gaps likely helped to produce the disinflation that occurred in 2003 and contributed to the deflation risk that inclined the Fed to keep the federal funds rate low. Broaddus and Goodfriend argue that the Fed ought to clarify its short-run concerns and intentions by referring to gaps in markups, employment, and output more prominently in its communications in order to make expected future federal funds rates conform more closely to the Fed's preemptive policy intentions. Talking in terms of gap indicators is controversial because of the unfortunate experience in the 1960s and 1970s, when calling attention to employment and output gaps created pressure that led to inflationary monetary policy and poor macroeconomic performance. Nevertheless, Broaddus and Goodfriend argue that times have changed and the Fed could deal with such pressures by announcing an explicit inflation target.

\section{CONCLUSION}

Monetary theory and policy have been revolutionized in the two decades since the Federal

${ }^{46}$ See McCallum (2004).
Reserve moved in October 1979 to stabilize inflation and bring it down. It is true that much of today's core theory and practice was already in place by October 1979. For instance, the stickiness of prices was understood to be important, current inflation was understood to depend on expected inflation, and inflation was understood to respond inversely to the output gap. But the advances were revolutionary nevertheless. On the side of practice, the decisive and revolutionary factor was the demonstration that monetary policy has the power to acquire and maintain credibility for low inflation so as to improve the stability of both inflation and output relative to potential. On the theory side, the introduction of rational expectations was decisive because it enabled models of monetary policy to incorporate forwardlooking elements of aggregate demand and price setting, long known to be critically important for policy analysis, so as to understand how monetary policy consistently committed to stabilizing inflation could achieve the favorable results found in practice. In short, the period since October 1979 was a remarkable one in which major parallel developments in both theory and experience reinforced each other, making monetary economists and central bankers both more confident of their respective advances.

\section{REFERENCES}

Ball, Laurence. "Credible Disinflaton with Staggered Price-Setting." American Economic Review, March 1994, 84, pp. 282-89.

Barro, Robert J. and Gordon, David B. “A Positive Theory of Monetary Policy in a Natural Rate Model." Journal of Political Economy, 1983, 91, pp. 589-610.

Bernanke, Ben S. and Mishkin, Frederic S. "Inflation Targeting: A New Framework for Monetary Policy?" Journal of Economic Perspectives, 1997, 11, pp. 97116.

Blinder, Alan S. "Central-Bank Credibility: Why Do We Care? How Do We Build It?" American Economic Review, December 2000, 90, pp. 1421-31. 
Blinder, Alan S. The Quite Revolution: Central Banking Goes Modern. New Haven, CT: Yale University Press, 2004.

Brayton, Flint; Levin, Andy; Tryon, Ralph and Williams, John. "The Evolution of Macro Models at the Federal Reserve Board." Carnegie-Rochester Conference Series on Public Policy, December 1997, 47, pp. 43-81.

Broaddus, J. Alfred Jr. and Goodfriend, Marvin. "Sustaining Price Stability." Federal Reserve Bank of Richmond Economic Quarterly, Summer 2004, 90, pp. 3-20.

Calvo, Guillermo A. "Staggered Prices in a Utility Maximizing Framework." Journal of Monetary Economics, September 1983, 12, pp. 383-98.

Cecchetti, Stephen G. "Inflation Indicators and Inflation Policy,” in Ben S. Bernanke and Julio J. Rotemberg, eds., NBER Macroeconomics Annual. Cambridge, MA: MIT Press, 1995, pp. 189-219.

Clarida, Richard; Galí, Jordi and Gertler, Mark. "The Science of Monetary Policy: A New Keynesian Perspective." Journal of Economic Literature, December 1999, 37, pp. 1661-707.

Cogley, Timothy and Sargent, Thomas J. "The Evolution of Postwar U.S. Inflation Dynamics,” in Ben S. Bernanke and Kenneth S. Rogoff, eds., NBER Macroeconomics Annual. Cambridge: MIT Press, 2001, pp. 331-73.

Cook, Timothy. "Determinants of the Federal Funds Rate: 1979-1982.” Federal Reserve Bank of Richmond Economic Review, January/February 1989, pp. 3-19.

Cook, Timothy and Hahn, Thomas. "The Effect of Changes in the Federal Funds Rate Target on Market Interest Rates in the 1970s." Journal of Monetary Economics, November 1989, 24, pp. 331-51.

Erceg, Christopher J.; Henderson, Dale W. and Levin, Andrew T. "Optimal Monetary Policy with Staggered Wage and Price Contracts." Journal of Monetary Economics, October 2000, 46(2), pp. 281-313.
Federal Open Market Committee. Transcripts. Washington, DC: Board of Governors of the Federal Reserve System, 1979-81.

Feldstein, Martin. "The Costs and Benefits of Going from Low Inflation to Price Stability," in Christina D. Romer and David H. Romer, eds., Reducing Inflation: Motivation and Strategy. Chicago: University of Chicago Press, 1997, pp. 123-66.

Fellner, William. "The Credibility Effect and Rational Expectations: Implications of the Gramlich Study." Brookings Papers on Economic Activity, 1979, 1, pp. 167-89.

Ferguson, R. "Why Central Banks Should Talk." Remarks at the Graduate Institute of International Studies, Geneva, Switzerland, January 2002.

Fischer, Stanley. "Modern Central Banking,” in Forrest Capie et al., eds., The Future of Central Banking: The Tercentenary Symposium of the Bank of England. Cambridge: Cambridge University Press, 1994, pp. 262-308.

Fisher, Irving. The Theory of Interest. Fairfield, NJ: Augustus M. Kelly, [1930] 1986.

Friedman, Milton. A Theory of the Consumption Function. Princeton: Princeton University Press, 1957.

Friedman, Milton. A Program for Monetary Stability. New York: Fordham University Press, 1960.

Friedman, Milton. Statement before the U.S. Congress, House of Representatives, Committee on Banking and Currency in The Federal Reserve System After Fifty Years. Subcommittee on Domestic Finance. Hearings, 88 Cong. 2 Sess. Washington, DC: U.S. Government Printing Office, 1964.

Friedman, Milton. "The Role of Monetary Policy." American Economic Review, March 1968, 58(1), pp. 1-17.

Friedman, Milton. "Quantity Theory of Money,” in John Eatwell, Murray Milgate, and Peter Newman, eds., The New Palgrave: Money. New York: W.W. Norton \& Company, 1989, pp. 1-40. 


\section{Goodfriend}

Fuhrer, Jeffrey and Moore, George. "Inflation Persistence.” Quarterly Journal of Economics, February 1995, 110(1), pp. 127-59.

Goodfriend, Marvin. "Monetary Mystique: Secrecy and Central Banking." Journal of Monetary Economics, 1986, 17, pp. 63-92.

Goodfriend, Marvin. "Central Banking Under the Gold Standard." Carnegie-Rochester Conference Series on Public Policy, Autumn 1988, 29, pp. 85-124.

Goodfriend, Marvin. "Interest Rates and the Conduct of Monetary Policy." Carnegie-Rochester Conference Series on Public Policy, Spring 1991, 34, pp. 7-30.

Goodfriend, Marvin. "Interest Rate Policy and the Inflation Scare Problem: 1979-1992.” Federal Reserve Bank of Richmond Economic Quarterly, Winter 1993, 79, pp. 1-24.

Goodfriend, Marvin. "Monetary Policy Comes of Age: A 20th Century Odyssey." Federal Reserve Bank of Richmond Economic Quarterly, Winter 1997, 83, pp. 1-22.

Goodfriend, Marvin. "The Phases of U.S. Monetary Policy: 1987 to 2001." Federal Reserve Bank of Richmond Economic Quarterly, Fall 2002, 88, pp. 1-17.

Goodfriend, Marvin. Book Review: Allan H. Meltzer, A History of the Federal Reserve, Volume I: 19131951. Federal Reserve Bank of Minneapolis The Region, December 2003a, 1, pp. 82-89.

Goodfriend, Marvin. "Inflation Targeting in the United States?” NBER Working Paper No. 9981, National Bureau of Economic Research, September 2003b (also in Ben S. Bernanke and Michael Woodford, eds., The Inflation Targeting Debate. Cambridge, MA: National Bureau of Economic Research, 2005, pp. 311-37).

Goodfriend, Marvin. "Monetary Policy in the New Neoclassical Synthesis: A Primer." Federal Reserve Bank of Richmond Economic Quarterly, Summer 2004, 90(3), pp. 21-45 (reprinted from International Finance, 2002, 5, pp. 165-92).
Goodfriend, Marvin. "Narrow Money, Broad Money, and the Transmission of Monetary Policy," in Faust, Jon, Athanasios Orphanides, and David Reifschneider, eds., Models of Monetary Policy: Research in the Tradition of Dale Henderson, Richard Porter, and Peter Tinsley. Proceedings of a Federal Reserve Board conference (March 26-27, 2004). Washington, DC: Board of Governors of the Federal Reserve System (forthcoming).

Goodfriend, Marvin and King, Robert G. "The New Neoclassical Synthesis and the Role of Monetary Policy," in Ben S. Bernanke and Julio J. Rotemberg, eds., NBER Macroeconomics Annual. Cambridge: MIT Press, 1997, pp. 231-82.

Goodfriend, Marvin and King, Robert G. "The Case for Price Stability," in A.G. Herrero et al., eds., First ECB Central Banking Conference, Why Price Stability? Frankfurt: European Central Bank, 2001, pp. 53-94; NBER Working Paper No. 8423, National Bureau of Economic Resarch, August 2001.

Greenspan, Alan. Statement before the U.S. Congress, House of Representatives, Subcommittee on Domestic Monetary Policy of the Committee on Banking, Finance and Urban Affairs, Zero Inflation. Hearing, 101 Cong. 1 Sess. Washington, DC: U.S. Government Printing Office, 1990.

Gurkaynak, Refet S.; Sack, Brian and Swanson, Eric. "The Excess Sensitivity of Long-term Interest Rates: Evidence and Implications for Macroeconomic Models." Finance and Economics Discussion Series 2003-50, Board of Governors of the Federal Reserve System, February 2003.

Hawtrey, R.G. A Century of Bank Rate. London: Longran, 1938.

Hetzel, Robert L. "Arthur Burns and Inflation." Federal Reserve Bank of Richmond Economic Quarterly, Winter 1998, 84, pp. 21-44.

Ireland, Peter. "Long-Term Interest Rates and Inflation: A Fisherian Approach." Federal Reserve Bank of Richmond Economic Quarterly, Winter 1996, 82(1), pp. 21-35.

Kerr, William and King, Robert G. "Limits on Interest Rate Rules in the IS Model.” Federal Reserve Bank 
of Richmond Quarterly Review, Spring 1996, 82, pp. 47-75.

King, Robert G. and Wolman, Alexander L. "What Should the Monetary Authority Do When Prices Are Sticky?” in John B. Taylor, ed., Monetary Policy Rules. Chicago: University of Chicago Press, 1999, pp. 349-404.

Kohn, Donald. "Comments on Marvin Goodfriend's 'Inflation Targeting in the United States?', in Ben S. Bernanke and Michael Woodford, eds., The Inflation Targeting Debate. Cambridge, MA: National Bureau of Economic Research, 2005, pp. 337-50.

Kydland, Finn and Prescott, Edward C. "Rules Rather than Discretion: The Inconsistency of Optimal Plans." Journal of Political Economy, June 1977, 85(3), pp. 473-91.

Lindsey, David; Orphanides, Athanasios and Rasche, Robert H. "The Reform of October 1979: How It Happened and Why." Federal Reserve Bank of St. Louis Review, March/April 2005, 87(2, Part 2), pp. 187-235.

Lucas, Robert E. Jr. "Econometric Policy Evaluation: A Critique." Carnegie-Rochester Conference Series on Public Policy, 1976, 1, pp. 19-46.

Lucas, Robert E. Jr. Studies in Business-Cycle Theory. Cambridge, MA: MIT Press, 1981.

McCallum, Bennett T. "Issues in the Design of Monetary Policy Rules,” in John B. Taylor and Michael Woodford, eds., Handbook of Macroeconomics. Amsterdam: Elsevier Science B.V., 1999, pp. 1483-530.

McCallum, Bennett T. "The United States Deserves a Monetary Standard.” Unpublished manuscript, Shadow Open Market Committee, 2000a.

McCallum, Bennett T. “Alternative Monetary Policy Rules: A Comparison with Historical Settings of the United States, the United Kingdom, and Japan.” Federal Reserve Bank of Richmond Economic Quarterly, Winter 2000b, pp. 49-79.

McCallum, Bennett T. “Monetary Policy Analysis in
Models without Money." NBER Working Paper No. 8174, National Bureau of Economic Research, 2001.

McCallum, Bennett T. "Misconceptions Regarding Rules vs. Discretion for Monetary Policy." Cato Journal, Winter 2004, 23(3), pp. 365-72.

Mankiw, N. Gregory and Romer, David H., eds. New Keynesian Macroeconomics. Volumes 1 and 2. Cambridge, MA: MIT Press, 1991.

Meltzer, Allan H. "The Demand for Money: The Evidence from the Time Series.” Journal of Political Economy, June 1963, 71, pp. 219-46.

Meltzer, Allan H. A History of the Federal Reserve. Volume 1: 1913-1951. Chicago: University of Chicago Press, 2003.

Okun, Arthur M. "Efficient Disinflation Policies." American Economic Review, May 1978, 68, pp. 348-52.

Orphanides, Athanasios and Williams, John C. "Inflation Scares and Forecast-Based Monetary Policy.” Review of Economic Dynamics, 2005 (forthcoming).

Poole, William. Money and the Economy: A Monetarist View. Reading: Addison-Wesley Publishing Co., 1978.

Poole, William. "Federal Reserve Operating Procedures: A Survey and Evaluation of the Historical Record Since October 1979." Journal of Money, Credit, and Banking, 1982, 14(4), pp. 575-96.

Romer, Christina D. and Romer, David H. "Does Monetary Policy Matter? A New Test in the Spirit of Friedman and Schwartz," in Oliver J. Blanchard and Stanley Fisher, eds., NBER Macroeconomics Annual. Cambridge, MA: MIT Press, 1989, pp. 121-69.

Sargent, Thomas J. Rational Expectations and Inflation. New York: Harper \& Row, 1986.

Schmitt-Grohé, Stephanie and Uribe, Martin. "Optimal Fiscal and Monetary Policy under Sticky Prices.” NBER Working Paper No. 9220, National Bureau of Economic Research, 2002. 


\section{Goodfriend}

Schreft, Stacey L. “Credit Controls: 1980.” Federal Reserve Bank of Richmond Economic Review, November/December 1990, pp. 25-55.

Shapiro, Matthew D. "Federal Reserve Policy: Cause and Effect,” in N. Gregory Mankiw, ed., Monetary Policy. Chicago: University of Chicago Press, 1994, pp. 307-34.

Svensson, Lars E.O. "Inflation Targeting as a Monetary Policy Rule.” Journal of Monetary Economics, June 1999, 43, pp. 607-54.

Taylor, John B. "Estimation and Control of a Macroeconomic Model with Rational Expectations." Econometrica, September 1979, 47(5), pp. 1267-86.

Taylor, John B. "Establishing Credibility: A Rational Expectations Viewpoint." American Economic Review Papers and Proceedings, May 1982, 72(2), pp. 81-85.

Taylor, John B. "Discretion Versus Policy Rules in Practice.” Carnegie-Rochester Conference Series on Public Policy, December 1993, 29, pp. 195-214.
Taylor, John B., ed. Monetary Policy Rules. Chicago: University of Chicago Press, 1999a.

Taylor, John B. "Staggered Price and Wage Setting in Macroeconomics,” in John B. Taylor and Michael Woodford, eds., Handbook of Macroeconomics. Amsterdam: Elsevier Science B.V., 1999b, pp. 1009-50.

Thornton, Daniel L. "When Did the FOMC Begin Targeting the Federal Funds Rate? What the Verbatim Transcripts Tell Us.” Working paper, Federal Reserve Bank of St. Louis, August 2004.

Tobin, James. "Stabilization Policy Ten Years After." Brookings Papers on Economic Activity, 1980, 1, pp. 19-71.

Woodford, Michael. Interest and Prices: Foundations of a Theory of Monetary Policy. Princeton: Princeton University Press, 2003. 